\title{
A Reachable Governance to Fight COVID-19: Democracy and the Legacy of Embedded Autonomy in Taiwan
}

\author{
Peters Li-ying Chen ${ }^{1}$ \\ ${ }^{1}$ Graduate Institute of National Development, National Taiwan University, Taiwan \\ Correspondence: No.63, Fuder Lane, Tungyang Rd. Fongyuan District, Taiching City, 420, Taiwan. E-mail: \\ peters.chen@gmail.com
}

Received: July 25, 2020

Accepted: September 3, 2020

Online Published: October 1, 2020

doi:10.20849/ajsss.v5i3.777

URL: https://doi.org/10.20849/ajsss.v5i3.777

\begin{abstract}
Different country showed different governing capacity to the COVID-19 pandemic in 2020. With reference to the classical concept of embedded autonomy, as used in developmental state of political theory, this paper aims to study the capacity and progression of democratic country, Taiwan, in its fight with the emergence of the COVID-19 pandemic and how democratic state, civil society and bureaucrats have affected the response and measures. Taiwan's case provides a valuable empirical contribution to the understanding of the long term effect of embedded autonomy in a democratic country. This study argues that democracy does matter to fight Covid-19 pandemic, moreover, the legacy of embedded autonomy can be expanded beyond economic development, and successfully used to explain Taiwan's capacity to fight the COVID-19 pandemic in its early stage. Key observations and discussion addressed in this study includes, first, the extent to which the concept of embedded autonomy is applicable in evaluating and in shaping Taiwan's efforts to manage the pandemic; second, the extent to which the political system is better at managing COVID-19 crisis by comparing democratic Taiwan and authoritarian China. A central finding of this paper is that, democracy has proven it has the edge in coping with COVID-19 pandemic practically. Theoretically, Taiwan's case demonstrates a valuable and supplementary example to Evans and Heller (2018) on their broadening view of embedded autonomy. The legacy of the developmental state is applicable to explain Taiwan's immediate and effective response to the COVID-19 outbreak. A reachable governance to fight COVID-19 lies in 'the nature of democracy' and 'the legacy of embedded autonomy'.
\end{abstract}

Keywords: democracy, Taiwan, embedded autonomy, developmental state, COVID-19 pandemic, authoritarian, China

\section{Introduction}

The COVID-19 pandemic severely affected the public health and economic development all over the world in 2020. The outbreak is also a crisis of political system and its governance in different country. Emergencies like this provided the conditions for governmental leaders to expand their powers. Many webinars (Note 1) on the future of democracy or the rise of authoritarianism in COVID-19 world had been hosted since the pandemic happened. There has been ample discussion about whether authoritarian or democratic governments have been the most effective to manage the crisis (Note 2). Some media seemed to tout the superiority of China's response to the Western countries, by expressing praise of China's draconian lockdown after the Wuhan outbreak (Trofimov, 2020). German Chancellor Angela Merkel also told Germany's parliament on April 23, "this pandemic is an affront to democracy because it restricts our existential rights and needs."(Spengler, 2020) Meanwhile, democracies like South Korea and Taiwan had some of the best responses anywhere on the planet (Beauchamp, 2020). Academic circles are making efforts to find out the key that determines a nation's resistance to the COVID-19. If democratic system is one of the reliable factors, what else? More than two decades ago, Evans (1995) indicated embedded autonomy was the main feature of developmental states, like Taiwan, when it was an authoritarian country. Recently, Evans and Heller (2018) broadened their views of the concept of developmental state out of economic terms. This article argued that Taiwan, as a democratic country now, its case contributed as a supplementary example for their broadening views on embedded autonomy, as well as a reachable governance to fight COVID-19 pandemic. Therefore, this study has both practical and theoretical significance. 


\section{Review: Democracy and Embedded Autonomy}

As written in the first line of a summary of the Congressional Research Service of the US in 2010, "Taiwan, which its government formally calls the Republic of China (ROC), is a success story for U.S. interests in the promotion of universal freedoms and democracy" (Kan, 2010). Experts including Diamond (Diamond 2011; Diamond et al., 2014), have categorized Taiwan's democracy consolidated and essentially irreversible. Taiwan has seven times presidential direct election since the first one in 1996, and it worked well with the party system to consolidate the democracy, by having three transitions of power between the two opposition parties. Mountains of paper and barrels of inks have been devoted to studying on Taiwan's democratization (Jacobs, 2007) and now Taiwan has been widely acknowledged as one of the most democratic countries in Asia (Schafferer, 2015). Apart from the important definition of democracy as "procedural democracy" and "free and fair election" (Note 3), "fuzzy norms" which were discarded by Huntington (1993) as a useful analysis may pave a way in this article to find out the difference between democratic Taiwan and authoritarian China against COVID-19. It is the nature of democracy, at least, including openness and transparency, accountability, being a part of community life, and its sincerity, which can be taken as fuzzy norms.

Dahl (1963) extracted three characteristics of democracy, including popular sovereignty, political equality and majority rule. In addition, his theory of "polyarchy"(Dahl, 1971; 1998) stressed that societal actors operate autonomously and independently from the state. This paper narrows the exploration of autonomous societal actors by applying the legacy of "embedded autonomy" to the context, which exists in Taiwan and strengthens its state capacity to fight COVID-19. The concept of embedded autonomy appeared more than two decades ago within the larger context of the developmental state literature. Evans (1995) persuasively argued that developmental states combined two traits, autonomy and embeddedness. His study indicated that the ideal type of Weberian bureaucracy enabled states to formulate a coherent vision of industrial policy while avoiding predatory practices. A maze of ties connected technocrats and industries provided institutional channels for collective action. Major point made by the developmental state literature (Evans, 1996a; 1996b; Heller, 1996; Ostrom, 1996) was to describe state-society relationships in terms of embedded autonomy. This connection was the key feature of East Asian developmental states, including Taiwan. From an authoritarian state to a democratic state, Wade (2018) believed that democratic changes, financial reforms and the diversified development in the past few decades has made it no longer useful to define a state like Taiwan as developmental states in terms of economy. However, the conception of embedded autonomy was a breakthrough which can be extended beyond the developmental state and beyond economic transformation. As Evans and Heller (2018) examined how state structures and possibilities for state action in Asia have been shaped by geo-political context and history, they also stated "the developmental value of competent, coherent state apparatuses remains undeniable. The ability to preserve such states, and create them where they do not yet exist, will be a prime determinant of Asia's future path."

During the COVID-19 at the beginning of 2020, the ties that connect civil society and state across the public private divide have not disappeared in today's democratic Taiwan. The mechanism functioned as Evans (1996) described, "these ties allow public officials to facilitate the building of networks and civic engagement among citizens, which, in turn, state agencies leverage to generate developmental effects". This insight can be exploited to full potential and applied to a wider range of state capacity when coping with the emergent public health crisis, rather than in economic transformation only. Facing on infectious novel coronavirus disease beginning at the end of 2019, with the nature of democracy, Taiwan proved an empirical case in favor of strengthening the state capacity by its legacy of embedded autonomy.

\section{Methodology}

The main contents of this study include theory of democracy, Taiwan's governance, the theory of developmental state, and its concept of embedded autonomy, and the development and reaction of governments on fighting COVID-19 pandemic. In order to have comprehensive study and better interpretation of literature to address this topic, literature review are the main method that conducted in this research. In the part of theories, literature review provides a comprehensive survey of classical book and papers that published in the fields of democratic theory and the research of embedded autonomy over a specified period of time, which helped this paper on systematically understanding and combining the literature to identifying a gap in the existing research bases. It also established the importance of this topic within the academic community in this area of study by carving a space for news findings to uncover areas in which more discussion is needed, which is a critical supplement of building theoretical model.

It is in the context of fighting COVID-19 pandemic that this study attempts to get a wider and latest view of the 
developing situation on ground. In addition to literature review on the theoretical parts, the daily news, articles, magazines, and presses are very important for a new and undergoing topic. Thus, observation are used to gather information to explore, document, and realize as the pandemic occurred, country's governance, policies and measures, leadership, the operation of political system, citizens' responses, and so on.

\section{Findings Part I: Response to COVID-19 in Taiwan}

This part attempts to demonstrate the extent to which precautions took place in Taiwan to fight COVID-19 in general from December of 2019 to June of 2020.

On 30 January in 2020, WHO declared the Coronavirus outbreak a Public Health Emergency of International Concern (PHEIC). On 11 March, the WHO Director General characterized COVID-19 as a pandemic. (Note 4) However, Taiwan responded it and took measures earlier than WHO's, beginning from the end of 2019. When the first news about a mysterious illness in Wuhan started emerging in December 2019, Taiwan treated the news with utmost urgency (Yip, 2020) With only 80 miles separation from China, Taiwan has 23 million citizens of which 1.25 million Taiwanese people were working and living in China (Pan, 2020), moreover, 2.71 million visitors from the mainland traveled to Taiwan in 2019. Therefore, there is a high frequency of flights and travelers between China and Taiwan. Johns Hopkins University had then predicted Taiwan would have the second most COVID-19 cases in the world (Woodruff, 2020). However, the reverse is true. From June 22, Taiwan permitted business travelers from 15 countries and territories classified as low risk, when it recorded 56 straight days without any domestically transmitted infections till June 7 (Yen, 2020). On June 23, it kept the total at 446 since the pandemic began late last year, according to the Taiwan Centers for Disease Control (2020). On the same day, COVID-19 had infected 9,210,430 patients in 213 countries and regions, including 2,388,225 in the U.S. (Note 5)

In Taiwan, Deputy Director-General of the Centers for Disease Control (CDC), Lo Yi-chun, was surfing on internet of Taiwan's Reddit-like platform, PTT, around 2 o'clock in the early morning of December 31, 2019. The post shares a number of screengrabs taken from different Chinese online forums, including an announcement from Wuhan's health department dated December 30, 2019, which notes that a number of patients with pneumonia of unknown etiology were recorded and demanded medical institutions in the city report to the department if there were a case with similar symptoms (Yang 2020). "He quickly reported it to the top of his organization around $5 \mathrm{o}$ 'clock in the morning. The health official also wrote an email the same day to the World Health Organization (WHO), stating his worries and requesting its attention as well as any available information about the coronavirus. The email, according to Minister Chen Shih-chung, should have been taken seriously, given the WHO staff's medical backgrounds. Apparently, however, it was not. (Yang 2020)"

At the end of 2019, most Taiwanese were actually focused on the presidential campaign and its election on January 11, 2020, as well as the New Year firework show at Taipei 101. In response to the information obtained on December 31, Taiwan's Center for Disease Control took measures early on, including inspecting plane passengers coming from Wuhan starting December 31, 2019. Residents from Wuhan were banned from coming back on January 23, 2020, and tours to China were also suspended on January 25, and Taiwan eventually banned all Chinese visitors on February 6. "Taiwan's anti-coronavirus strategy utilizes a combination of early vigilance, proactive measures, and information sharing with the public, as well as applying technology in the form of analyzing big data and online platforms. All this is done with an impressive level of public transparency and engagement, in stark contrast to China's use of draconian and coercive measures and censorship to handle the coronavirus outbreak. (Yip, 2020)"

As the pneumonia outbreak caused by COVID-19 in China has obviously resulted in community transmission and spread, in terms of mechanism, Taiwan's Ministry of Health and Welfare established its Central Epidemic Command Center (CECC) on January 20. (Note 6) The first case, a female who came back from Wuhan, was announced on 21 January 2020. CECC has conducted daily briefings to give transparent information to the public, starting on 21 January 2020. Taiwanese government acted quickly to integrate Taiwan's national health insurance database with its immigration and customs database, enabling medical professionals to access patients' travel history going back two weeks. In addition, it increased stockpiles of personal protective equipment (PPE) for healthcare workers, predesignated potential isolation wings and hospitals, and created a daily nationwide inventory of available intensive care and negative-pressure isolation rooms, including the number that could be refitted when needed (Lin et al., 2020).

Taiwan's Prime Minister Su Tseng Chang, on January 24, announced the temporary halt in exports of face masks to ensure enough supplies in Taiwan. 90 percent of masks are imported, thus, Taiwan is left with no choice but to produce masks domestically. At the end of January, the Cabinet proposed to build 60 assembly lines to produce 6 
million surgical masks a day, with plans to increase daily production to 10 million. On February 6, Taiwan Machine Tool \& Accessory Builders' Association (TMBA) encouraged the members to volunteer and help the country. The first troop of the "national team" was set up in just five days. Many companies joined on February 21 to support Taiwan's mask equipment manufacturers. Around 140 people from 29 enterprises, from upstream to downstream, from the machine tool industry and 3 industrial Institutes joined the national team, including managers, factory directors and senior technicians, with an average of 10 years of experience in the industry. The 60 production lines, which normally take four to six months to complete, were set up in 25 days - before the scheduled one-month deadline (Taiwan Trade, 2020). The number of masks produced in Taiwan reached at least 10 million daily in March and 13 million in April, moreover, on April 6, Taiwan donated a total of 10 million surgical masks to its diplomatic allies, 11 European countries and the U.S. (Taiwan Today, 2020)

Before Taiwan had a sufficient supply of masks, long lines could be seen outside most pharmacies. Building on basic information provided by the government, several netizens with IT skills set about creating application programming interfaces (APIs) that would show data on pharmacy locations and mask supplies. Howard Wu, one of the first engineers to develop a relevant API before the government's rationing program was launched, said its purpose was to provide information on mask stocks at convenience stores, where they were being sold primarily at the time (Lee, 2020). Then, government released NHI data about pharmacy location, Wu was able to upgrade his API, using Google Maps to show the locations of pharmacies and whether they had mask stocks. A paper from the Stanford School of Medicine (Duff-Brown, 2020) stated that Taiwan engaged in 124 discrete action items to prevent the spread of the disease, before March 2.

Economically, on February 27, the Cabinet proposed a special budget up to US\$1.97 billion to go toward funding the central government's fight against the outbreak of COVID-19 together with economic stimulus and relief measures, including hospital quarantine and treatment, medical worker compensation and equipment, and so on. Within that, US\$1.33 billion is going to finance assistance for industries including manufacturing, tourism and transportation, agriculture, arts and cultural enterprises, and businesses in indigenous and Hakka communities. Sectors catering to domestic demand - such as food service, retail, night markets, shopping districts and traditional markets - are also be targeted. Among specific measures aimed at minimizing the economic impact are financing guarantees and interest subsidies for corporations, transportation industry tax subsidies, payments to support travel accommodation operations, agricultural marketing assistance, and consumer purchase vouchers for domestic demand-focused businesses as well as arts and cultural enterprises. (Note 7) The budget, planned according to the Special Act on COVID-19 Prevention, Relief and Recovery, was unanimously passed by the Taiwanese Parliament 16 days after it was proposed.

\section{Findings Part II: The Nature of Democracy Matters}

To have better understanding on which political system is better at managing COVID-19 crisis, this part shows the strengths of democracy by comparing democratic Taiwan and authoritarian China, The nature of democracy, including openness and transparency, accountability, being a part of community life, and its sincerity, help us to pave the way to address a democratic governance at this unusual battle.

\subsection{Openness and Transparency}

For autocratic leaders, the word democracy evokes visions of disorder or chaos and they may take tumult as a companion to democracy. However, it is because a "democratic society is openness and transparency, which promise the public access to information. On the other hand, a democratic government also has to take responsibility for communicating with people because leaders are accountable to the public. Only when we ensure the free flow of information in a democracy can we construct a healthy society. (Pu, 2020)" In the initial stage of COVID-19, Taiwan took a technocratic approach to counter the pandemic with honest, transparency and public trust by holding a press conference every day to announce the latest information on the epidemic and to clarify rumors, one that is in line with its liberal and democratic values. While in China, an authoritarian regime, the priority of governance in facing this crisis is to maintain social stability and control information. In the beginning, officials attempted to clamp down on unusual cases of illness that looked like pneumonia. "Although researchers released the virus's genetic sequence in record time, local officials underreported cases, downplayed the risk of human-to-human transmission, and detained the doctor who discussed the disease (Berengaut, 2020)". Dr. Li Wenliang is said one of the doctors who later died of complications from COVID-19.

\subsection{Accountability}

Modern political democracy is a system of governance in which rulers are held accountable in the public realm (Schmitter et al., 1991). Taiwan takes accountability to be at the core of democracy. People are able to expect a high level of candor, accountability and judicial system from the government. Therefore, the provided 
information and figures every day are accurate and reliable. During a coronavirus task force briefing on China's COVID-19 pandemic at the White House by Dr. Deborah Birx, the President of the United States, Donald Trump repeatedly asked reporters, "Does anybody really believe this number? (Shinkman, 2020)" The White House coronavirus response coordinator Dr. Deborah Birx stressed "the need for countries to report accurately how a new disease has affected their populations, particularly those countries that were among the first to experience it (Shinkman, 2020)."

\subsection{Community Life}

Based on the public trust and government accountability, democratic countries make "community life" possible, which people of different views and strengths can discuss the crisis together and find out a feasible solution. When people refer to "being a part of the community", it is a collaborative actions through sharing in and helping of others. This can be popularly seen in many democratic nations. In the US, many volunteers rushed to help New York City hospitals in the beginning of April (Hong, 2020). In Taiwan, people donated to local people and foreign countries as well, for example, to Italy. Italian Father Giuseppe Didone in Taiwan issued an open letter thanking Taiwanese for donating NT $\$ 120$ million (US\$3.97 million) in six days to a fundraising campaign he launched to help fight the new coronavirus outbreak in Italy (Shen et al., 2020).

\subsection{Sincerity: Different Mask Diplomacy}

It is people's freedom to contribute to their society through active involvement. Small and medium business in Taiwan involved and took responsibilities to produce surgical masks is vital in rebuilding the community after the outbreak. Furthermore, Taiwan donated 10 million surgical masks to its allies, the US and the Europe (Chen, 2020), that were all made in Taiwan after the COVID-19 pandemic. Contrary to Taiwan, China covered up the extent of the coronavirus outbreak to stock up on medical supplies needed to respond to it, according to a four-page Department of Homeland Security intelligence report dated May 1 in the US (Weissert, 2020). Before pandemic, "roughly 2 bn masks were imported into China in February. (Subramanian, 2020)" The US state of Missouri then went on to do just that, arguing in its lawsuit that China had "hoarded personal protective equipment. (Subramanian, 2020)" In late March, the Chinese government made the first move in Helsinki, approaching their Finnish counterparts and offering to sell protective face masks (Dunst, 2020). China's so-called "mask diplomacy" is evidently untrusted, by that "some 80 percent of the masks the Czech Republic purchased from China for around US\$600,000 are defective. Chinese rapid-testing kits sold to Spain had only 30 percent sensitivity, as opposed to the 80 percent level expected. (Dunst, 2020)"

The new cases as second wave outbreak in Beijing (Taylor, 2020) in June reminded us that the coronavirus can return at any time and also showed that authoritarian regime may be much more fragile than it trumpeted on its success in containing the coronavirus. Although Fukuyama (2020) thinks that "the issue is not whether democracies or authoritarian do better", the analysis of political system of Taiwan and China leads us to the conclusion that, "if political regimes are judged by how they have responded to the pandemic, a democratic depression seems unlikely. Covid-19 has exposed the flaws of authoritarianism while showing the strengths of democracy (Frey, 2020)", based on its nature.

\section{Discussion: Applicable Embedded Autonomy}

\subsection{Responsive Bureaucrats}

In developmental states, connectedness normally means ties between industrial elites and the state. However, this paper argues that embedded autonomy exists in both bureaucrats and civil society, and their connectedness shapes the state capacity to cope with an emergency like the COVID-19 pandemic. Taiwan's democratic system might reduce the power of regime control, yet enhance the important of bureaucrats in the government and its connectedness to the society. This part has considered one factor that most people take into account when they think about bureaucrats, that is, reliability. The perception of reliability may somehow come from qualification or educational degree of these bureaucrats. Well-educated and knowledge-based bureaucracy in Taiwan plays a key role in its administration system, which also gains public trust from people to some extent.

Civil servants in Taiwan are selected through a competitive exam system, similar to elite civil service in many countries. By the end of 2018, there were 356,878 civil servants in Taiwan's government. Among them, 91.11\% of the civil servants hold bachelor's degrees and $23.37 \%$ of the total hold master or PhD degrees (Textor, 2020). For many young people, civil service is a decent choice for their career plan, however, it is highly competitive. As mentioned above, Lo Yi-chun, Deputy Director-General of CDC, is one of the bureaucrats, who graduated from National Taiwan University that ranked No. 66, according to QS World University Ranking in 2020. Even at ministerial level, traditionally, Taiwan always has a $\mathrm{PhD}$ cabinet, which means most ministers are with $\mathrm{PhD}$ 
degrees in different professions, from the U.S. or European countries. This has been taken as a kind of warranty of governing capacity of the ruling party.

Additionally, pressures for administrative reform have been strong since the 1990s, Taiwan has launched its reinventing reforms along the lines of ideas and practices of new public management, new public service, public private partnership, corporatization and commercialization. Nowadays, principles like responsiveness are fostered in bureaucracy by turning to new forms of governance which are "more society-centred" and focus on "co-ordination and self-governance". (Peters, 1995; Pierre, 2000) An empirical study on Taiwan shows that, "bureaucrats or the so-called permanent civil servants root their own legitimacy not only in separated powers or autonomous expertise, but in their ongoing collaboration with legislators and publics. They define their own accountability not just as executing legislative mandates but as producing them in the first place, and they figure bureaucracy as a key site for political participation." (Bernstein, 2019) While party always has certain connection to some groups of people, the neutral civil service serves all people to provide public service, no matter what the ruling party is. Therefore, bureaucrats act responsively and, to some extent, autonomously with regard to policy issues. This may explain why Taiwan's officials and its team members warned of the Wuhan epidemic earlier than other countries, through a post from PTT, which is a vibrant networking forum representing vibrant civil society. At that moment, most people focused on the Presidential campaign and 2020 New Year celebration. Led by Chen Shih-Chung, Taiwan's Minister of Health and Welfare, most members of CECC are civil servants with degrees in medical studies or public health. In order to respond to the public and provide correct information as soon as possible, CECC has held press conference at 14:00 every afternoon since January 21 . The mutual trust, education and connectedness were established between the bureaucrats and the people through the daily dialogue.

\subsection{Vibrant Civil Society}

After a few decades of democratization, Taiwan's civil society has tremendously grown. In this pandemic, netizens contributed their part as well. Ever since the outbreak of COVID-19, respiratory masks became the key piece of equipment everyone wanted to buy. From the perspective of civil society, in Taiwan, netizens of different backgrounds have banded together in the virtual world. Social media platforms, private companies, and regular citizens, including the previously mentioned Howard $\mathrm{Wu}$, came up with numerous online services or Apps that visualized the quantity of masks in stock at different locations. Other netizens invented text-based chatbots in "LINE" that provide information on where to purchase masks. People have created dozens of privately and independently maintained tools and information platforms on the internet (Lin, 2020). Later, in order to work together and improve the platforms, Minister without portfolio Audrey Tang and the National Health Insurance Administration helped to release NHI data on pharmacy locations and mask stocks and established a rationing system for a more precise information system.

Far surpassing original targets, at the beginning of April, a team of technicians spent 6 weeks assembling 92 surgical face mask production lines that boosted the country's daily production capacity from 4 million to 13 million masks per day, representing the support from the manufacturing industry. The thriving biomedical industry in Taiwan is also taking part in the development of therapeutics and vaccines; Silmitasertib (CX-4945) is one promising candidate being investigated (Chiou, 2020). These all proved the autonomy of energetic civil society to make efforts with bureaucracy to combat virus. The society did not stand aloof from the outbreak, on the contrary, civil society strongly connected to bureaucracy, and the state.

\subsection{State Capacity: Effective Governance}

The degree of autonomy that characterizes developmental states is the product of historical circumstance rather than a social pact between capital and the state (Evans, 1995). In "the state and development", Evans and Heller (2018) stressed that the comparative history of Asian states offers many development theories and policy possibilities. The autonomy could come from threat and fear. Given that Taiwan has faced everything from its giant neighbor - the spreading of fake news, military threats, the withholding of vital medical information during the SARS(Severe Acute Respiratory Syndrome) (Note 8) outbreak in 2003 - the country knows it must be on its fullest guard whenever any major problem emerges in China (Yip, 2020). The historical and continuous threat has been toward Taiwan for more than 70 years and provides a good explanation of the scenario, which has put Taiwanese in an earlier stage of awareness concerning every emerging event from China, including this unknown disease. Taiwan is locked out of the World Health Organization (WHO) and all international organizations because of China, that is, Taiwan has to rely on itself for everything. This background naturally formed its awareness of autonomy. With this high degree of autonomy always embedded in state, bureaucracy and civil society, Taiwan demonstrates that state capacity needs to be proactive and take multiple measures it deems 
necessary, especially on an emergent crisis.

The immediate ban on exportation of mask and building of 92 assembly lines, later on more than that, to produce surgical masks showed the autonomy of the state in fighting against COVID-19, as did the APP of mask purchase and other strict measures. In order to increase mask production, the government immediately invested US\$6.66 million to have new supply lines, and recruited a national team of 140 technicians to assemble them at requisitioned manufacturing facilities. The other measures included drastically cutting inbound flights from China and imposing quarantines on travellers early on, which experts say was key in stopping the COVID-19 spread in the community, as well as strict surveillance measures on those in quarantine. (Note 9)

Within the context of increased digitalization, the state is also expected to play an increasing role in mitigating the potentially negative effects on society and promoting innovation-led growth, thus calling for a higher level of social inclusion. Different from traditional discussion of developmental state in economy, the so called embedded autonomy has existed for a long time and has been shared among state, civil society and bureaucrats in every aspect in Taiwan. Strong state may act as a catalyst to the civil society, and vice versa. The lessons from Taiwan to fight against COVID-19 pandemic showed a more collaborative approach once the bureaucracy reacted immediately after finding a number of patients with pneumonia of unknown etiology were recorded in China, with similar symptoms to SARS.

Seeing that the initial response to SARS was hampered by the lack of a centralized decision making body to take charge during a health crisis, Taiwan later that year authorized the creation of a Central Epidemic Command Center (CECC) to coordinate across government departments and mobilize the necessary resources during future crises (Shapiro, 2020). Therefore, this time, Taiwanese government soon established CECC, to deploy monitoring measures, reallocate national resources and provide transparent information.

\subsection{Democracy Paved the Way}

As mentioned, embedded autonomy was built around ties to bureaucrats and civil society as well. Netizens firstly developed new apps to help purchase and control on limited masks. Industries actively took the responsibility to work together to produce masks, with competitors, which is an effective public-private collaboration. People obeyed every rule that government announced every day and kept schools and business normally operating. There must be acknowledgement of the media that has helped by broadcasting correct information and basic preventive knowledge such as washing hands and wearing masks. Additionally, in order to prevent the transmission of misinformation and disinformation, "Taiwan established the Taiwan FactCheck Center, and each department currently has a Meme Engineering team. When it discovers misinformation or disinformation online, the team will verify it within sixty minutes and clarify it to the public immediately." (Tu, 2020) The nature of democracy as mentioned above has paved the way for its people to get used to lead a legal and democratic life on this island.

In addition to technology and big data applications, another reason Taiwan autonomously acted so early is decisions from professional leaders. Taiwan's Vice President Chien-jen Chen received a Doctor of Science degree in epidemiology and human genetics from the Johns Hopkins Bloomberg School of Public Health in 1982. Vice president-elect William Lai, who will be assuming office on May 20, 2020, got his Master's degree in Harvard School of Public Health. President Tsai Ing-wen, who was praised as a decisive female leader, holds a $\mathrm{PhD}$ degree from London School of Economic and Political Sciences. Professional knowledge helps the leader make the best decisions possible, and efficiently. Meanwhile, adult literacy rate for Taiwan was $98.5 \%$ in 2019, which means people were equipped with basic education on public health and this made it possible for regulations or measures to be correctly and easily put into force. Few people have noted this significance of this education foundation.

Under a democratic system, the concept of embedded autonomy is still applicable in evaluating and shaping Taiwan's management of the pandemic. Thus, when Evans and Heller tried to expand the scope of state-society links to include a broader range of sectors, the case of Taiwan managing the COVID-19 pandemic would has been a supplementary example in this field. It contributed to Evans and Heller's broadening view of development and result in a more nuanced version of the embedded autonomy analysis.

\section{Conclusion}

This paper has sought to provide a critical analysis of Taiwan's capacity and progression in fighting the COVID-19 pandemic by using the nature of democracy and the concept of embedded autonomy, which has existed in state, bureaucrats and civil society. This study firstly outlined the responses to COVID-19 pandemic in Taiwan. From perspective of political system, the paper started picturing the difference of democratic Taiwan 
and authoritarian China in this issue. Based on the foundation of democracy, this article described the reaction and measures taken in Taiwan much earlier than any other countries because of its democratic essence of openness, transparency, accountability, feeling of community life, and sincerity. The nature of democracy does matter. In addition to democracy, state capacity plays an important role. The roles and autonomy of state, bureaucrats and civil society were examined by immediate policy and measures, which also showed responsiveness and vibrant action in industry and internet world. Empirical examples have provided a more detailed understanding of interactions among state, bureaucracy and civil society, including posts on public forums, early warnings to government and WHO, big data, information systems and Apps for purchasing masks, and so on. Taiwan's bureaucracy and civil society enjoyed a considerable level of autonomy. Taiwanese shared collective memory of different kinds of threat from China and the SARS outbreak in 2003. Thus, the state always has a high level of embeddedness and autonomy for a long run. The legacy of the embedded autonomy of the state of Taiwan was found in the way the state deployed the national team to manufacture masks, then in distribution, as well as the inbound flight ban, mask exportation ban, and budget for economic stimulus, mask diplomacy, etc.

With the nature of democracy with state capacity, Taiwan has proven it has the edge in coping with COVID-19 pandemic. This paper has broadened the conceptual space of embedded autonomy by examining the interaction among the state, bureaucracy and civil society in Taiwan while fighting against COVID-19. Beyond economic growth traditionally, Taiwan's case revealed that the concept of embedded autonomy, as a legacy of developmental state, is applicable to explain its immediate and effective response to the COVID-19 outbreak. A reachable governance to fight COVID-19 lies in 'the nature of democracy' and 'the legacy of embedded autonomy'.

\section{Acknowledgements}

High tribute shall be paid to Prof. Sue Babcock, whose profound knowledge of English triggers my love for this studying and whose expert guidance on my writing. My heartfelt thanks should go to my wife Anthea who has put considerable time and effort into taking care of my kids in India during this COVID-19 pandemic period.

\section{References}

Beauchamp, Z. (2020). VOX, The myth of authoritarian coronavirus supremacy. Retrieved April 10, 2020, from https://www.vox.com/2020/3/26/21184238/coronavirus-china-authoritarian-system-democracy

Berengaut, A. A. (2020). The Atlantic, Democracies Are Better at Fighting Outbreaks. Retrieved June 9, 2020, from https://www.theatlantic.com/ideas/archive/2020/02/why-democracies-are-better-fighting-outbreaks/606976/

Bernstein, A. (2019). Porous Bureaucracy: Legitimating the Administrative State in Taiwan. Law \& Social Inquiry, 45(1). 28-51. Retrieved April 18, 2020, from https://www.cambridge.org/core/journals/law-and-social-inquiry/article/porous-bureaucracy-legitimating-th e-administrative-state-in-taiwan/311DEF7DEAF29BE3927F1542F03D2B1E\#

Chen, S. (2020). abcNews. Taiwan to donate 10 million masks to countries hit hardest by coronavirus. Retrieved June 1 , 2020, from https://abcnews.go.com/Health/taiwan-donate-10-million-masks-countries-hit-hardest/story?id=69918187

Chiou, C. (2020). How Taiwan Battles the Coronavirus. The Diplomat, Retrieved April 6, 2020, from https://thediplomat.com/2020/04/how-taiwan-battles-the-coronavirus/

Dahl, R. A. (1963). Preface to democratic theory. Chicago: University of Chicago Press, p. 64.

Dahl, R. A. (1971). Polyarchy; participation and opposition. New Haven, Yale University Press, pp. 1-32

Dahl, R. A. (1998). On democracy. New Haven: Yale University Press, pp.85-86.

Diamond, L., \& Shin, G. S. (Eds.) (2014). New Challenges for Maturing Democracies in Korea and Taiwan. CA: Stanford University Press.

Diamond, L. (2011). East Asia amid the Receding Tide of the Third Wave of Democracy. International Conference on Democracy in East Asia and Taiwan in Global Perspective, National Taiwan University, Taipei, August 24-25, 2011, p. 1.

Duff-Brown, B. (2020). How Taiwan Used Big Data, Transparency and a Central Command to Protect Its People from Coronavirus. Freeman Spogli Institute for International Studies and the Stanford School of $\begin{array}{lllll}\text { Medicine. } & \text { Retrieved } & \text { April } & 14, & \text { 2020, }\end{array}$ 
https://healthpolicy.fsi.stanford.edu/news/how-taiwan-used-big-data-transparency-central-command-protect -its-people-coronavirus

Dunst, C. (2020). The American Interest, How China's Mask Diplomacy Backfired. Retrieved May 9, 2020, from https://www.the-american-interest.com/2020/04/15/how-chinas-mask-diplomacy-backfired/

Evans, P., \& Heller, P. (2018). The State and Development. WIDER Working Paper Series 112, World Institute for Development Economic Research (UNU-WIDER).

Evans, P. (1995). Embedded Autonomy: States and Industrial Transformation. NJ: Princeton University Press.

Evans, P. (1996). Government Action, Social Capital and Development: Reviewing the Evidence on Synergy. World Development, 24(6), 1119-1132.

Evans, P. (1996). Introduction: Development Strategies across the Public-Private Divide. World Development, 24(6), IN1-IN1, 1033-1037.

Frey, C. B. (2020). Financial Times, Democracies have proven they have the edge in coping with this crisis. Retrieved June 19, 2020, from https://www.ft.com/content/5d08522e-99b2-11ea-871b-edeb99a20c6e

Fukuyama, F. (2020). supchina, Francis Fukuyama: COVID-19 Is Threatening Global Democracy And Peace, in an interviewed by Audrey Jiajia Li. Retrieved June 10, 2020, from https://supchina.com/2020/05/01/francis-fukuyama-interview-covid-19/

Heller, P. (1996). Social Capital as a Product of Class Mobilization and State Intervention: Industrial Workers in Kerala, India. World Development, 24(6), 1055-1071.

Hong, N. (2020). New York Times. Volunteers Rushed to Help New York Hospitals. Retrieved May 9, 2020, from https://www.nytimes.com/2020/04/08/nyregion/coronavirus-new-york-volunteers.html

Huntington, S. P. (1993). The Third Wave: Democratisation in the Late Twentieth Century. Oklahoma: University of Oklahoma Press.

Jacobs, B. (2007). Taiwan and South Korea: Comparing East Asia's Two "Third-Wave" Democracies. Issues and Studies, 43(4), 227-260

Kan, S. A. (2010). Democratic Reforms in Taiwan: Issues for Congress. Congressional Research Service, R41263, May 26.

Lee, H. (2020). Tech experts helped make Taiwan's mask rationing system a success. Retrieved April 16, 2020 from https://focustaiwan.tw/society/202002280019

Lin, C., Braund, W. E., Auerbach, J., Chou, J-H., Teng, J-H., Tu, P., et al.. (2020, July). Emerging Infectious Disease, Policy decisions and use of information technology to fight 2019 novel coronavirus disease. Taiwan, 26(7). https://doi.org/10.3201/eid2607.200574

Lin, G-T. (2020). Common Wealth Magazine, Civic Tech Versus COVID-19: Online Map and Reservation System Help Fight the Virus. Retrieved April 19, 2020, from https://english.cw.com.tw/article/article. action?id=2668

Ostrom, E. (1996). Crossing the Great Divide: Coproduction, Synergy, and Development. World Development, 24(6), 1073-1087.

Pan, T.. \& Yeh, J. (2019, December 17). Number of Taiwanese working in China hits 10-year low. Focus Taiwan. Retrieved April 13, 2020, from https://focustaiwan.tw/business/201912170022

Peters, G. (1995). The Future of Governing. Lawrence, KN: University Press of Kansas.

Pierre, J. (Ed.) (2000). Debating Governance. Oxford: Oxford University Press. PS21 Office. 2001. Public Service for the Twenty-first Century. Singapore: PS21 Office, pp .2-6.

$\mathrm{Pu}, \mathrm{V}$. (2020). The Diplomat, The Coronavirus Outbreak: How Democratic Taiwan Outperformed Authoritarian China. Retrieved April 12, 2020, from https://thediplomat.com/2020/02/the-coronavirus-outbreak-how-democratic-taiwan-outperformed-authoritar ian-china/

Schafferer, C. (2015). Taiwanese Democracy. In Howe, B. (Ed.), Democratic Governance in Northeast Asia: A Human-Centered Approach to Evaluating Democracy (pp. 105-129). Security, Development and Human Rights in East Asia. Palgrave Pivot, London.

Schmemann, S. (2020). The Virus Comes for Democracy Strongmen think they know the cure for Covid-19. Are 
they right?. New York Times, April 2.

Schmitter, P., \& Terry, K. (1991). What democracy is ... and is not. Journal of Democracy, 2(3), 75-88.

Schumpeter, J. A. (2013). Capitalism, Socialism and Democracy. London: Routledge.

Shapiro, D. (2020). Taiwan shows its mettle in coronavirus crisis, while the WHO is MIA. Retrieved April 19, 2020 , from https://www.brookings.edu/blog/order-from-chaos/2020/03/19/taiwan-shows-its-mettle-in-coronavirus-crisi s-while-the-who-is-mia/rus-crisis-while-the-who-is-mia/

Shen, W., \& Mazzetta, M. (2020). Focus Taiwan, Priest thanks Taiwanese for NT\$120 million in donations for Italy. Retrieved May 9, 2020, from https://focustaiwan.tw/society/202004070008

Shinkman, P. D. (2020). U.S. News and World Report, Trump Challenges China, Iran Reporting on the $\begin{array}{lllll}\text { Coronavirus. } & \text { Retrieved } & \text { May } & \text { 2020, from }\end{array}$ https://www.usnews.com/news/national-news/articles/2020-04-18/trump-challenges-china-iran-reporting-on -the-coronavirus

Spengler. (2020). Asia Times, Covid-19 is 'an affront to democracy'. Retrieved April 10, 2020, from https://asiatimes.com/2020/04/covid-19-is-an-affront-to-democracy/

Subramanian, S. (2020). The Guardian, How the face mask became the world's most coveted commodity. Retrieved May 9, 2020, from https://www.theguardian.com/world/2020/apr/28/face-masks-coveted-commodity-coronavirus-pandemic

Taiwan CDC. (2020). Taiwan Centers for Disease Control. Retrieved June 23, 2020, from https://www.cdc.gov.tw/En

Taiwan Today. (2020). Taiwan donates 10 million surgical masks to allies, US, Europe. Retrieved April 15, 2020 from https://taiwantoday.tw/news.php?unit=2,6,10,15,18\&post=174874

Taiwan Trade. (2020). A Bravery Story - A Taiwan National Machine Tool Team for Surgical Mask Production born to fight against COVID-19 outbreak. Retrieved April 15, 2020, from https://www.taiwantrade.com/news/a-bravery-story-a-taiwan-national-machine-tool-team-for-surgical-mask -production-born-to-fight-against-COVID-19-outbreak-1979557.html\#

Taylor, A. (2020). The Washington Post, Beijing's new coronavirus outbreak carries an urgent message for the world. Retrieved June 19, 2020, from https://www.washingtonpost.com/world/2020/06/18/beijing-coronavirus-outbreak-meaning/

Textor, C. (2020). Statista, Number of all civil servants in Taiwan in 2018, by education level. Retrieved April 18, 2020, from https://www.statista.com/statistics/953173/taiwan-number-of-civil-servants-by-education-level/

Trofimov, Y. (2020). The Wall Street Journal, Democracy, Dictatorship, Disease: The West Takes Its Turn With $\begin{array}{lllll}\text { Coronavirus. } & \text { Retrieved } & \text { April } & 10, & \text { 2020, }\end{array}$ https://www.wsj.com/articles/democracy-dictatorship-disease-the-west-takes-its-turn-with-coronavirus-115 83701472

Tu, C-C. (2020). Lessons from Taiwan's experience with COVID-19, Atlantic Council. Retrieved April 22, 2020, from https://atlanticcouncil.org/blogs/new-atlanticist/lessons-from-taiwans-experience-with-COVID-19

Wade, R. (2018). The Developmental State: Dead or Alive? Development and Change. Forum 2018, 49(2), 518-546

Weissert, W. (2020). The Associated Press, DHS report: China hid virus'severity to hoard supplies. Retrieved May 9, 2020, from https://apnews.com/bf685dcf52125be54e030834ab7062a8

Woodruff, J. (2020). PBS News Hour, Taiwan's aggressive efforts are paying off in fight against COVID-19. Retrieved April 13, 2020, from https://www.pbs.org/newshour/show/taiwans-aggressive-efforts-are-paying-off-in-fight-against-COVID-19

Yang, S. (2020). Taiwan News, Evidence of Taiwan health official learning about Wuhan virus human-to-human transmission in Dec. Retrieved April 17, 2020, from https://www.taiwannews.com.tw/en/news/3917429

Yen, W. (2020). Focus Taiwan, Business travelers with shortened quarantine relatively safe: experts. Retrieved June 22, 2020, from https://focustaiwan.tw/society/202006220014

Yip, H. (2020). Foreign Policy, Fear of China Made Taiwan a Coronavirus Success Story. Retrieved April 10, 2020, from https://foreignpolicy.com/2020/03/16/taiwan-china-fear-coronavirus-success/ 


\section{Notes}

Note 1. See Cameron, David R. (2020). Webinar on Democracy and Rise of Authoritarianism in COVID-19 World. The MacMillan Center's councils and the Yale Law School, Retrieved May 5, 2020, from ttps://www.youtube.com/watch?v=weWzfa-52Ew\&feature=youtu.be

Note 2. For example, New York Times put it, "China and some of its acolytes are pointing to Beijing's success in coming to grips with the coronavirus pandemic as a strong case for authoritarian rule.", according to Schmemann, S. (2020). The Virus Comes for Democracy Strongmen think they know the cure for Covid-19. Are they right?. New York Times, April 2.

Note 3."Procedural democracy": Huntington followed joseph Schumpeter in redefining democracy in the term of procedures for constituting government; "free and fair election": Larry Diamond contributes the rules of free and fair election in defining democracy. Schumpeter, J.A. 1883-1950. (2013). Capitalism, Socialism and Democracy. ebook ISBN: 9780203202050, London: Routledge.

Note 4. See World Health Organization. (2020). Coronavirus disease (COVID-19) outbreak, Retrieved April 12, 2020, from https://www.who.int/westernpacific/emergencies/COVID-19

Note 5. See Worldometer. (2020). COVID-19 Coronavirus Pandemic. Retrieved June 23, 2020, from https://www.worldometers.info/coronavirus/

Note 6. Taiwan's Ministry of Health and Welfare established its Central Epidemic Command Center (CECC) on January 20, which was the first one all over the world then, with integrated and command function to coordinate with different ministries. See Ministry of Health and Welfare website. (2020). 成立「嚴重特殊傳染性肺炎中央 流行疫情指揮中心」, Retrieved May 1, 2020, from https://www.mohw.gov.tw/cp-16-51157-1.html

Note 7. See Executive Yuan. (2020). Executive Yuan approves special budget to fund COVID-19 response. $\begin{array}{llr}\text { Retrieved April } & 16, & 2020,\end{array}$ https://english.ey.gov.tw/Page/61BF20C3E89B856/06d49065-d457-41ae-aae1-8a4d3450abcd

Note 8. In Taiwan, the SARS epidemic in 2003 caused 73 deaths on the island country of 23 million people.

Note 9. See BBC News. (2020). Why Taiwan has become a problem for WHO. Retrieved April 19, 2020, from https://www.bbc.com/news/world-asia-52088167

\section{Copyrights}

Copyright for this article is retained by the author(s), with first publication rights granted to the journal.

This is an open-access article distributed under the terms and conditions of the Creative Commons Attribution license (http://creativecommons.org/licenses/by/4.0/). 